DOI https://doi.org/10.32405/2218-7650-2020-13(42)-305-318

Удк 811.111: 81'373.72

Faramazov Azer Suratullah oghlu,

Lecturer, Department of Foreign Languages,

Lenkaran State University.

Lenkaran city, Republic of Azerbaijan.

ORCID iD: https://orcid.org/0000-0002-7601-9985

islamagaev1702@gmail.com

\title{
ENGLISH PHRASEOLOGICAL UNITS WITH TEMPORAL MEANING: SEMANTIC CHARACTERISTIC
}

\begin{abstract}
The article is devoted to the problem of phraseological units with temporal meaning, which are analyzed from the point of view of their semantic integrity, structure and means providing their stability and cohesion. The object of the study are phraseological units connected with the notion of time, containing the names of the days of the week, seasons, parts of the day and generalizing words in English. The phraseological units, which are the subject of this study, were identified by sampling from monolingual and bilingual phraseological dictionaries, from explanatory dictionaries of the Russian and English languages, from synonymous dictionaries of the Russian and English languages. Before proceeding with the analysis of phraseological combinations with temporal meanings, we consider the lexeme time, which is the base of them; distinguish its basic and peripheral meanings. We also try to analyze the structure of the lexical-semantic field time, define its lexical-semantic groups, scrutinize it from the point of view of phraseological activity. Trying to clarify the system organization of temporal phraseological units, we consider the field approach applied by many researchers that allowed us to identify the phraseological macrofield of time and phraseological microfields, containing certain differential semes. An interesting and important part of the research is the problem of communicative-pragmatic functions of phraseological units with the component time. The relevance of this study is that acquaintance with phraseology, including phraseological units with temporal meaning, allows not only natural and emotional communication, nut a deeper understanding of the history of the people, their attitude to human strengths and weaknesses, the specifics of their worldview.
\end{abstract}

Keywords: phraseological unit; lexical and semantic groups; the category of time; field approach; communicative-pragmatic functions. 


\section{INTRODUCTION / ВCTУП}

The intensive development of phraseology over the past decades has raised many problems. The world of phraseology of modern English is large and diverse, and every aspect of its research, of course, deserves due attention. Phraseological units reflect a special vision of the world, situations, inherent in native speakers. Researchers in this area of linguistics believe that phraseological units of any language are peculiar and most capacious translators of ethno culture, because due to the predominance of connotative meaning in them (motivation, emotiveness, and appraisal), they reflect a «biased» perception of the most significant objects of reality.

The focus of modern linguistics is border issues related to concepts that have connection with other sciences. In fact, almost all manifestations of a person's life, his birth and death, characteristics of character, mental activity, age, appearance, professional qualities, etc. - all this is clearly and peculiarly reflected in the phraseological systems of languages. They occupy a central place in the pictures of the world of many national-linguistic communities, as they form the basis, the foundation of the whole worldview.

A special place among the concepts belongs to the so-called universal, basic concepts. The concept of time, along with the concept of space, is one of the fundamental in the human knowledge system about the world. The perception and reflection of time is carried out differently in different cultures and, accordingly, is displayed differently in the language system and in phraseology in particular. The temporal conceptual sphere is one of the most significant in the minds of native English speakers. The phraseological units of this subsystem cover the spheres of general conceptual correlation: when analyzing them, both common features inherent in the human team, regardless of linguistic affiliation, and specific features caused by purely extralinguistic factors are revealed. This easily explains the continuing interest of researchers in the problems of representing temporal concepts in language and speech [1].

As recognized by most phraseologists, the linguistic nature of phraseology is determined primarily by its semantics, therefore, the selection for the analysis of phraseological units on a semantic basis seems to be the most justified. The linguistic aspect of the category of time (temporality) is the totality of the means by which language expresses the essence of the physical and philosophical aspects of this category. One of the significant means of expressing temporary relations in any language, including English, is phraseological units. Therefore, the subject of our research is phraseological units representing temporal relations in the English language. The choice of this subsystem as an object of 
study is not accidental. The research results indicate that the study of the entire phraseological system, characterized by complexity and inconsistency, can be successful only with a thorough analysis of its individual microsystems, which have common and specific features inherent in the whole system as a whole.

With this in mind, we selected for analysis a numerous and characteristic for the English language subsystem of phraseological units, semantically oriented to the concept of «time». It is this phraseological subsystem that is a clear example of the action of not only linguistic, but also extralinguistic factors in the language. Indeed, in the English language, the phraseological units of this subsystem cover the spheres of general conceptual correlation: when analyzing them, both common features inherent in the human team, regardless of language, as well as specific features due to purely extralinguistic factors, are revealed.

Literature Review / Аналіз останніх досліджень і публікацій. In modern linguistic research, the study of phraseological units that denote the concept of «time» in English is a relevant and promising area. Much attention is paid to the study of semantics and pragmatics of phraseological units denoting certain concepts and their invariants in English, the researches of modern linguoconceptology (A. Prikhodko, Yu.Stepanov, B. Serebrennikov, V. Timofeeva,), but the study of semantic variability of phraseological units with the component «time» (O. Afanasyeva, O. Selivanova) and their functional features is not sufficient, which is the relevance of this article. Based on the research of Ukrainian and Russian scientists (O. Afanasyeva, Yu. Feshchenko, M. Kopylenko, Yu. Pradid, Z. Popova, V. Timofeeva), we propose to consider the problem of this issue.

Based on the analysis of monolingual and bilingual phraseological dictionaries, we tried to identify English idioms and phrases related to the semantic field of time. The phraseological units, which are the subject of this study, were identified by sampling from monolingual and bilingual phraseological dictionaries, from explanatory dictionaries of the Russian and English languages, from synonymous dictionaries of the Russian and English languages. The basis was «Longman Dictionary of English Idioms», «Longman Dictionary of Contemporary English», «Oxford Advanced Learner's Dictionary of Current English», «Cambridge Advanced Learner's Dictionary», «MerriamWebster's Dictionary», «Wordsmith Dictionary Thesaurus», «Oxford Dictionary of English Etymology». Information was also used from dictionaries such as «English-Russian Phraseological Dictionary» (Kunin), «Phraseological Dictionary of the Russian Literary Language» (Fyodorov), «Phraseological Dictionary of the Russian Language» (Molotkov) and other publications, «The Dictionary of Phraseological Synonyms of the Russian Language» (Zhukov), 
«Explanatory Dictionary of the Russian Language» (Ozhegov), «Etymological Dictionary of Russian Phraseology» (Shansky).

\section{AIM AND TASKS / META TA ЗАВДАННЯ}

The purpose of the study is a comprehensive description of phraseological units with temporal meaning, including the components time, hour, minute, moment, second.

In accordance with this goal, the article sets the following tasks: to make a selection of the indicated phraseological units from the linguistic material of the English language; to systematize the studied material from different aspects; to analyze the specific features and characteristics of phraseological units with the meaning of time and their functions in communicative situations.

\section{THE THEORETICAL BACKGROUNDS / TEOPETИЧНI ОСНОВИ ДОСЛІДЖЕННЯ}

Over the long period of the English language existence, a huge number of expressions, which are considered to be very successful and beautiful, have been accumulated in it. Thus, a special layer of language arose - phraseology, which includes a set of stable expressions that have independent meaning. Phraseology (Greek phrasis - «expression», logos - «teaching») is a section of linguistics that studies stable combinations in a language.

The question of the existence of phraseology, its categorical features is one of the central in the theory of phraseology. Phraseological units are a reflection of the linguocultural picture of the world and attract the attention of many linguists. Phraseology as a science presents great opportunities for studying not only the linguistic structure of a particular language, but also allows you to identify the cultural specifics, customs and worldviews of people speaking this language. Good knowledge of the language is impossible without knowledge of its phraseology. Reading English literature, newspapers, scientific articles, or just watching the news, you can meet incomprehensible expressions phraseological units, idioms. With the help of various phraseological expressions and idioms, the language is supplemented with useful and interesting phrases, with the help of which the description of our world, life, emotions and other things becomes much easier.

Being the main part of the phraseological system of the language, phraseology is a complex and multi-aspect unit, «difficult to distinguish from the total number of words and phrases, and therefore difficult to determine» [2]. A. Kunin under the term «phraseologism» means «a separately formed combination of words with a variable meaning and stability not lower than the 
minimum at the phraseological level» [2].

In our research work, we study phraseological units associated with the category of time, which is a universal and unified system.

\section{RESEARCH METHODS / МЕTОДИ ДОСЛІДЖЕННЯ}

To achieve our goal, we used the following methods: analysis of the current state of the problem; classification of criteria and indicators; a number of methods of phraseological identification proposed by professor A. Kunin, component analysis, field approach, as well as some methods of cognitive linguistics, method of quantitative calculations.

\section{RESEARCH RESULTS / РЕЗУЛЬТАТИ ДОСЛІДЖЕННЯ}

Before proceeding with the analysis of phraseological combinations with temporal meanings, we consider the lexeme time, which is the base of them: this particular lexeme is the unifying link of the time macrofield, which includes lexical and semantic groups of the periphery, consisting of time representing lexemes of various parts of speech - nouns, verbs, adjectives and adverbs.

After analyzing the meaning of the lexeme time in modern English, based on a number of English dictionaries - «Longman dictionary of Contemporary English», «Oxford Advanced Learner's Dictionary of Current English», «Cambridge Advanced Learner's Dictionary», «Merriam-Webster's Dictionary», «Wordsmyth Dictionary Thesaurus» - basic and peripheral meanings have been distinguished. The basic meanings are as follows: 1) passing days «I lived in Switzerland for a long time»; 2) measured period (in hours, minutes, etc) «Close relationships established over a long period of time»; 3) duration (in the past, present, future) «It took her a long time to make decision»; 4) period associated with smth «By the time we reached home»; 5) period for realization of smth «He writes poetry in his spare time»; 6) occasion, event «I've told you a dozen times»; 7) leisure «time for reading».

The peripheral meanings include: 1) system for measuring time «Pacific Time»; 2) historical period «ancient times»; 3) period in a sports game «first time of the game»; 4) number of beats in music «Waltzes are usually in three-four time»; 5) term (of apprenticeship, service, etc.) «computer time»; 6) multiplication «two-four time»; 7) season «time of year» [3].

Phraseological groups of the subject under study are quite numerous; however, a quantitative advantage is still observed on the side of phraseological units that reflect time.

In the structure of the lexico-semantic field time, researchers define the following lexical-semantic groups: 
- Nominations of time: time, term, epoch, era, age, season, era, period;

- Time measurement units: year, month, moment, instant, second, minute, hour, week, day, century;

- Calendar cycle: morning, noon, evening, night, midnight, winter, spring, summer, autumn;

- Time measuring: clock, watch, hand, chronometer, sun-dial, calendar, chronology, Greenwich;

- Adverbs with a time meaning: now, long ago, in time, again, sometimes, late, early, at once, for ever, suddenly, soon, long, quickly, on time, always, some day, finally, late, constantly, soon, immediately, forever;

- Time actions: time flies, passes, comes, goes away, heals, comes to an end, remains, erases, waits (does not wait);

- Actions taken over time: lose, find, spend, pass, kill, have, run out of, devote (the time), plan, take away, give, dedicate, wait, kill (time);

- Time characteristics: long, inexorable, late, old, present, winter, summer, future, good, excellent, lost, cruel, past, endless); ancient; oldfashioned, prehistoric, far.

The category of time in English has a multicomponent and multilayer organization. The core includes those lexical units that are characterized by the greatest concreteness of the semantics of time (LSG 1 and LSG 2). The periphery of the time field is represented by lexemes with more abstract features, most of which are characteristics of time, representing a vivid, memorable image of time [3].

From the point of view of phraseological activity, the component time is the most productive, firstly, because of its frequency, and secondly, by the time of origin, the word time is ahead of the other components of the phraseological units with temporal meanings. Phraseological units with components minute, moment, second constitute a smaller fraction of the studied material These components indicate short time and transmitting it are close in their meanings are interchangeable: this (very) minute / second; a moment / minute/ second. The component hour in the phraseological units can be both singular and plural: by the hour, at all hours [4].

Trying to clarify the system organization of temporal phraseological units, researchers applied the field approach. So, the phraseological macro field of time has eight phraseological microfields, containing certain differential semes. They define the following phraseological microfields:

- Repeatability is characterized by differential semes such as «constantly» (all the time, twenty-four hours a day), «sometimes» (at times, (in) between times), «often» (times out of / without number). 
- Duration includes differential semes «long» (half the time, have all the time in the world), «very long» (from time out of mind), «not very long» (Living on borrowed time, don 't be half an hour), «instantly» (at a moment's notice, on the spur of the moment; in no time (at all) / in less than no time / in next to no time).

- The time interval consists of phraseological units containing semets period characterized by a state of (peace in our time), a period characterized by activity (pass (the) time, spar for time), parts of the day - «morning» (the (wee) small hours of the morning), «night» (the witching hour / time (of night).

- The measurement of time is the smallest in volume, which can be explained by the lack of the need to convey this concept using phraseology. Phraseological units of this microfield indicate the time on the clock and are characterized by semes right («keep good time»), wrong (keep bad time, lose time).

- A time point is associated with a particular action, good or wrong time to start something. This includes phraseological units with the meaning of favorable moment - take time by the forelock, (theie's) no time like the present. And also phraseological unit with the meaning «unfavorable moment» - (at) an unearthly hour, at all hours (of the day / night), bad time.

- Temporal relationships reveal the complexity and diverse relationships within the category of «beginning / end of action» (there's (got to be) a first time for everything, the time is up), «simultaneity» (at the same time time), «preceding» ((in) the womb of time, before one's time), «sequence» (at a time, by the time that), «earliness» (ahead of time, time), «timeliness» (dead in time, on an hour)), «untimeliness» (out of hours, behind time), "almost late» ((at) the eleventh hour, at the last minute).

- Time scale reflect the category of «present, past, future». "Present group» - for the time being, up to the minute, abreast of / up with the times. This also include seme «modern» (change / keep up with the times - «to accept and adapt oneself to modern changes, ideas, opinions etc».

- Group «past» - the good old times, for old times' sake, in one's time, in times gone by, once upon a time; out-of-date ((be) behind (one's) time / the times, old before one's time - older m looks, physical condition, mental outlook, etc than is right or reasonable for one's age.

- Group «future» - a matter of time, time to come, in (the) course / fullness of time, (all) in good time.

- Time estimate express the subjective characteristic of time. From the point of view of human perception, depending on his/her emotional and physical state, time can be subjectively long (time hangs heavily on sb 's hands) or subjectively short (time flies). Or a person evaluates time as pleasant (have a high 
old time, have a rare old time of it, have the time of one's life), or as unpleasant (a bad quarter of an hour, a bad time, lean time, fall on hard times) [4].

Phraseological units of the subject under study comprise quite numerous groups, however, a quantitative advantage is nevertheless observed on the side of phraseological units reflecting time.

M. Ignatieva identifies the following temporal phraseological subgroups:

- Timeliness - untimeliness means timely (or untimely) coincidence with a certain moment of action (on the minute, on the dot, to the momen.

- Time period which include semes of the state of Nature along with the semes of time and time period (the dull season, Indian Summer). This phraseological group can also express negative meanings (dark [evil] days, hard times, a rainy day, dark hours).

- Intensity is connected with expression of such meanings as slowly (step by step, a bit at a time, at a snail's gallop, slow as a tortoise), seldom (every now and again, one time and another, from time to time).

- Subgroup Never is one of the brightest in the phraseological semantic field of time. The most interesting are the following phraseological units: when the devil is blind, when theEthiopian changes his skin, when hell freezes over, when pigs fly and other.

- Subgroup Long (a dog's age (a coon's age), till the cows come home, donkey's years, a month of Sundays) [5].

Phraseological units with temporal meaning can be quite diverse from the point of view of their structure. The most often distinguished structure in English are:

- $\mathrm{Adj} / \mathrm{C} /$ Part/Num + N

for example: better days, at a good hour, Monday feeling

- $\mathrm{C}+\mathrm{Conj}+\mathrm{Num} / \mathrm{Pr}+\mathrm{C}$

or example: day after day, a man of eighty winters, day by day, the night of death, week after week

- $\mathrm{Num}+\mathrm{Adj}+\mathrm{N}$

for example: one fine day

- Prn / the + N + Adv

for example: all night long

- $\mathrm{Pr}+\mathrm{N}+\mathrm{V}$

for example: in days to come

- with like, as

for example: like there's no tomorrow.

So, the most common structure is that including adjective, which gives 
attributive characteristic of the names of temporary dimensions. The dominant of the considered time dimensions in English are day, hour, night.

The English attributes to these words are mostly characterized by the neutrality of the transmitted meaning (long, olden, early, last, first, longest), although some opposite features are seen in the proposed assessment of the phenomenon. So, for example, the positive attributes happy, fair, fine contrast with attributes such as dying, drunken, rainy.

By the wealth of available attributive characteristics, day can be contrasted with night. The British, because of their uncategorical nature, are not limited to mere complaints (late, late, rainy, wet), and for this reason they quite confidently use phraseological units in their speech, where the night is shown in a new light, that is, like long, good, young, white.

The English hour is not also without negativity, transmitted through such attributes as dark, trying, ill, late, evil, devil.

However, it is combined with other attributes of a neutral or positive nature (small, unearthly, good, regular, solid).

Phraseological units with the component «time» and their corresponding invariants, which enrich their pragmatic potential, perform several occasional communicative-pragmatic functions in the discourse, such as:

- expressive function;

- figurative expressive function;

- cultural and encyclopedic function;

- social and informative function.

In certain communicative situations, phraseological units with the component time in English can simultaneously implement several occasional communicative-pragmatic functions. Thus, a typical feature of phraseological units with the component time in English is multifunctionality, which enhances the perlocutionary effect of the message and contributes to the achievement of the pragmatic goal. Phraseological units are easily adapted to the needs of the communicative situation due to the flexibility and dynamism of structure and semantics.

This feature of phraseological units leads to the emergence of various pragmatic connotations, which are detailed and clarified in accordance with specific pragmatic parameters of the communicative situation [4]. The pragmatic setting of such transformations is the interest of the addressee and the implementation of emotional and evaluative influence.

The synonymic row of the phrase-semantic fields presented here allow to assert that due to the flexibility of their semantics, phraseological units have the ability to be modified depending on the needs of the communicative situation 
and pragmatic goals, including positive or negative characteristic of time and its conceptual fields.

The universal basis of the semantics of phraseological units with the meaning of «time» is a phraseological image, the main function of which is to express a subjective, emotional and evaluative view of the world, bring linguistic facts closer to us, make them vivid, visual, aesthetically significant, existing really in our imagination. The phraseological image may be based on national traditions and customs, historical facts, biblical, fairy-tale and mythological subjects.

\section{CONCLUSIONS AND PROSPECTS FOR FURTHER RESEARCH / ВИСНОВКИ ТА ПЕРСПЕКТИВИ ПОДАЛЬШИХ ДОСЛІДЖЕНЬ}

As a result of the analysis, we can conclude that time is a complex language category, the lexical-semantic field of which is represented by numerous language nominations of this concept. The concept of time in English is a verbalized phrase-sematic and semantic field, the core of which is the component time, in the periphery of which are other components that denote the concept of time. That is, this structure follows the nuclear-peripheral model, which has the duration meanings as a center.

The near periphery is represented by the meanings of «time period», «moment», «cycle»; subconcepts «present», «past» and «future», which form a linear structural organization of time. The cyclic structural organization of time is represented at the level of the near periphery with the meanings «human life» (age), «life of nature» (seasons). The near periphery of the «moment» is represented by the subconcepts of «beginning», «end». An analysis of the potential seme words of the term «time» and the terms of subconcepts of time allows us to highlight the distant periphery of the concept, that can be distinguished as independent mental units: «youth», «old age», «maturity», «birth», «death», «seasons», «fast», «slow».

Phraseological units with a time meanings reflect the repeatability and duration of actions and phenomena. The studied phraseological units indicate time periods of different durations, a specific point in time, namely, a favorable or unfavorable moment. With the help of phraseologisms, the concept of measuring time is transmitted, as well as temporal relationships, such as the beginning or end of an action, precedence, sequence, earliness, timeliness or untimeliness of an action. Subjective perception of time is transmitted through phraseological units. Depending on the situation and condition of a person, time can be estimated as long or short, pleasant or unpleasant.

The phraseological units of the English language, united by the meaning of time, exhaustively reflect the concepts of «present-past-future». The peculiarity 
of the temporal meaning of phraseological units lies in its uncertainty: they do not denote any particular period of time, time has a generalized character in them. For time, expressed by phraseological units, abstractness is characteristic, which is manifested through lexico-semantic compatibility. The units under study explain the verb due to the meaning of phraseological uexpression with the meaning of the action time.

Prospects for further research / Перспективи подальших досліджень. We have studied the role of the nuclear component of phraseology to denote the universal concept of «time» in English, namely the component of «time» and its synonymous substitutes, which are also components of the conceptosphere, and this confirms the existence of semantic variance. The presented variant-synonymous series of thematic groups of data of phraseosemantic fields give grounds to assert that due to the flexibility of their semantics, phraseologies have the ability to be modified depending on the needs of the communicative situation and pragmatic goals, including positive or negative assessment of time and its conceptual fields. Phraseological units that verbalize the conceptual sphere of «time» and their invariants indicate specific ideas about the category of time in the English picture of the world and are a promising area of further research on the relationship of cognitive semantics and communicative pragmatics.

\section{REFERENCES (TRANSLATED AND TRANSLITERATED) / СПИСОК ВИКОРИСТАНИХ ДЖЕРЕЛ}

[1] Б.Ф. Цховребова, З.Н.Зангиева, «Семантические поля фразеологизмов, обозначающих свойства и качества характера человека со значением «обыкновенность», «заурядность», «болтливость», Фундаментальные исследования, № 12/11, с. 2501-2504, 2014.

[2] А.В.Кунин, Большой англо-русский фразеологический словарь. Москва, Россия: Русский язык, 1984.

[3] Е.Г. Семенова, «Атрибутивно-компонентная характеристика фразеологических единиц, содержащих наименования временных измерений, в современных английском и белорусском языках», Содружество наук. Барановичи-2017: на XIII Междунар. науч-практ. конф. молодых исследователей (Барановичи, 18-19 мая 2017 г.). [Электронный ресурс].

Доступно: http://rep.barsu.by/handle/data/3063

[4] И.П. Кудрявцева, «Фразеологические единицы современного английского языка с компонентами, обозначающими время time, hour, minute, 
moment, second», автореф. дис. канд. наук. Москва, 2007, 23 с.

[5] М. Э. Игнатьева, «Отражение времени и пространства во фразеологии русского и английского языков», автореф. дис. канд. наук. Казань, $2004,24 \mathrm{c}$.

\title{
АНГЛІЙСЬКІ ФРАЗЕОЛОГІЧНІ ПЕРЕГЛЯДИ З ТЕМПОРАЛЬНИМ ЗНАЧЕННЯМ: СЕМАНТИЧНІ ХАРАКТЕРИСТИКИ
}

\author{
Фарамазов Азер Суратуллах огли, \\ викладач кафедри іноземних мов \\ Ленкаранського державного університету. \\ Ленкаран, Азербайджанська Республіка. \\ ORCID iD: https://orcid.org/0000-0002-7601-9985 \\ islamagaev1702@gmail.com
}

Анотація. Статтю присвячено аналізу фразеологічних одиниць 3 часовим значенням, проаналізованих з погляду їх смислової цілісності, структури та засобів, що забезпечують їх стабільність та цілісність. Об’єктом дослідження є фразеологічні одиниці, пов'язані з поняттям часу, що містять назви днів тижня, пори року, частини дня та узагальнюючі слова в англійській мові. Фразеологічні одиниці, що $є$ предметом дослідження, були ідентифіковані шляхом вибірки 3 одномовних та двомовних фразеологічних словників, із тлумачних та синонімічних словників української, російської та англійської мов. Перш ніж приступити до аналізу фразеологічних сполучень із часовими значеннями, ми розглядаємо лексему time, які є їх основою, робимо спробу розрізнити ї̈ основні та периферійні значення. Також ми намагаємось проаналізувати структуру лексико-семантичного поля time, визначити його лексико-семантичні групи, уважно вивчити його 3 погляду фразеологічної активності. Намагаючись уточнити системну організацію фразеологічних одиниць із значенням time, ми розглядаємо польовий підхід, застосований багатьма дослідниками, який дозволив нам виявити фразеологічне макрополе time та фразеологічне мікрополе, що містять певні диференціальні семи. Цікавою та важливою частиною дослідження $\epsilon$ проблема комунікативно-прагматичних функцій фразеологічних одиниць із значенням час. Актуальність дослідження полягає в тому, що знайомство з фразеологією, включаючи фразеологічні одиниці з часовим значенням, дозволяє не тільки природне та емоційне спілкування, але глибше розуміти історію народу, їхнє ставлення до людських сильних і слабких сторін, специфіку їх світогляду. 
Ключові слова: фразеологічна одиниця; лексичні та семантичні групи; категорія часу; польовий підхід; комунікативно-прагматичні функції.

\title{
АНГЛИЙСКИЕ ФРАЗЕОЛОГИЧЕСКИЕ ЕДИНИЦЫ С ВРЕМЕННЫМ ЗНАЧЕНИЕМ: СЕМАНТИЧЕСКАЯ ХАРАКТЕРИСТИКА
}

\author{
Фарамазов Азер Суратуллах оглы, \\ преподаватель кафедры иностранных языков \\ Ленкаранского государственного университета. \\ Ленкаран, Азербайджанская Республика. \\ ORCID iD: https://orcid.org/0000-0002-7601-9985 \\ islamagaev1702@gmail.com
}

Аннотация. Статья посвящена анализу фразеологических единиц с временным значением, проанализированных с точки зрения их смысловой целостности, структуры и средств, обеспечивающих их стабильность и целостность. Объектом исследования являются фразеологические единицы, связанные с понятием времени, содержащих названия дней недели, времени года, части дня и обобщающие слова в английском языке. Фразеологические единицы, которые являются предметом исследования, были идентифицированы путем выборки из одноязычных и двуязычных фразеологических словарей, с толковых и синонимических словарей украинского, русского и английского языков. Прежде чем приступить к анализу фразеологических сочетаний с временными значениями, мы рассматриваем лексему time, которая является их основой, пытаемся различить ее основные и периферийные значения. Также мы стараемся проанализировать структуру лексикосемантического поля time, определить его лексико-семантические группы, внимательно изучить его с точки зрения фразеологической активности. Пытаясь уточнить системную организацию фразеологических единиц со значением time, мы рассматриваем полевой подход, примененный многими исследователями, который позволил нам выявить фразеологическое макрополе time и фразеологическое микрополе, содержащих определенные дифференциальные семи. Интересной и важной частью исследования является проблема коммуникативно-прагматических функций фразеологических единиц со значением время. Актуальность исследования заключается в том, что знакомство с 
фразеологией, включая фразеологические единицы с временным значением, позволяет не только естественное и эмоциональное общение, но глубже понимать историю народа, их отношение к человеческим сильных и слабых сторон, специфики их мировоззрения.

Ключевые слова: фразеологическая единица; лексические и семантические группы; категория времени; полевой подход; коммуникативно-прагматические функции.

\section{REFERENCES (TRANSLATED AND TRANSLITERATED)}

[1] B. F. Ckhovrebova, Z. N. Zangieva, «Semanticheskie polya frazeologizmov, oboznachayushchih svojstva i kachestva haraktera cheloveka so znacheniem «obyknovennost'», «zauryadnost'», «boltlivost'», Fundamental'nye issledovaniya, № 12/11, s. 2501-2504, 2014.

[2] A.V. Kunin, Bol'shoj anglo-russkij frazeologicheskij slovar'. Moskva, Rossiya: Russkij yazyk, 1984.

[3] E. G. Semenova, «Atributivno-komponentnaya harakteristika frazeologicheskih edinic, soderzhashchih naimenovaniya vremennyh izmerenij, v sovremennyh anglijskom i belorusskom yazykah», Sodruzhestvo nauk. Baranovichi-2017: na XIII Mezhdunar. nauch-prakt. konf. molodyh issledovatelej (Baranovichi, 18-19 maya 2017 g.). Dostupno: http://rep.barsu.by/handle/data/3063

[4] I. P. Kudryavceva, «Frazeologicheskie edinicy sovremennogo anglijskogo yazyka s komponentami, oboznachayushchimi vremya time, hour, minute, moment, second», avtoref. dis. kand. nauk. Moskva, 2007, 23 s.

[5] M. E. Ignat'eva, «Otrazhenie vremeni i prostranstva vo frazeologii russkogo i anglijskogo yazykov», avtoref. dis. kand. nauk. Kazan', 2004, $24 \mathrm{~s}$. 